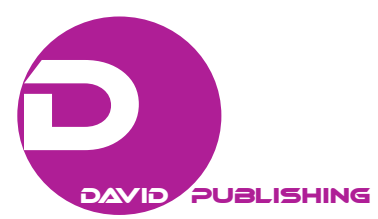

\title{
Structure Reorganization Due to IT Information Functions Support for Knowledge Management
}

\author{
Katarzyna Tworek, Katarzyna Walecka-Jankowska, Janusz Martan \\ Wrocław University of Technology, Wrocław, Poland
}

\begin{abstract}
In the introduction of the paper, there is a description of information technology and its potential role in knowledge management in organizations. First part of article describes which knowledge management process is crucial for innovation-oriented organizations (in order to conclude what are the factors influencing structure reorganization to better facilitate innovation). It is determined through stepwise regression analysis of various factors which can influence the degree of innovation of organization. Four main knowledge management processes are included among the factors. Therefore, next part of article describes information technologies (IT) functions which can be necessary for the IT to support knowledge acquisition—one of knowledge management processes. Discussion concerning the problem of selecting IT function most important in innovation-oriented organization is included. After that, there are presented research results concluding if IT information function (as an important component which allows the knowledge acquisition) can influence organizational innovation by facilitating reorganization to organic-type structure (more adequate for innovation-oriented organizations). Conclusion of the article is that organizations with implemented IT information function operate based on more organic-type structure (which is significantly better for innovation-oriented organizations) then those, in which IT information functions are not implemented.
\end{abstract}

Keywords: information technology (IT), innovation, knowledge management

\section{Introduction}

In today's world, the saying of Francis Bacon, that "knowledge is power", has a true mining. Rapid access to information is a critical factor of success for many organizations (Liao, 2003) and enables innovation, so knowledge management is an important field of studies. Information technologies (IT), defined as technologies which allow the change of course of employment with the organization and its main elements are: hardware, software, telecommunications networks, and stations working (Crowston, 2000), are an important factor for knowledge management in organizations. Along with the changes in the world at the turn of the century, it almost became a necessity to use IT in knowledge management for the organization benefits. Therefore, it is important to determine how important the IT role in knowledge management for the organization is. Thus, the main subject of this paper is to determine if IT can really influence innovation through knowledge management.

Katarzyna Tworek, Ph.D., Eng., Wrocław University of Technology, Wrocław, Poland.

Katarzyna Walecka-Jankowska, Ph.D., Eng., Wrocław University of Technology, Wrocław, Poland.

Janusz Martan, Ph.D., professor, Wrocław University of Technology, Wrocław, Poland.

Correspondence concerning this article should be addressed to Katarzyna Tworek, Wroclaw University of Technology, Wyb. Wyspianskiego 27, 50-370, Wroclaw, Poland. E-mail: katarzyna.tworek@pwr.edu.pl. 


\section{Knowledge Management in Organization}

Knowledge management has no clear definition, which would be widely accepted by both practitioners and theorists. Definitions of knowledge management presented in the literature often focus on the areas of knowledge management in organizations - it is process approach — based on consulting company experience, the main emphasis is on knowledge management process like acquisition, transfer, and codification (for this approach, characteristic is logic and ordering, but knowledge is identified as an information). However, the emphasis in process approach is not always located on all processes - some are focused on the processes of transfer and sharing, some on the possibility of acquiring knowledge. There are two more-resource approach and "Japanese". Resource shows how organizations generate and use knowledge. It is based on strategic approach and knowledge is identified as most important resource, which should be managed to be competitive advantage. Japanese concentrates on creating and breading knowledge in social interaction process between tacit and explicit knowledge, so the most important thing in this approach is definition of tacit and explicit knowledge. But the practical side of the model is very poor, so it cannot be used in organization. Instead, it is implemented as a part of model. The synthesis of tree approaches to knowledge management was used in research. According to resource approach model which shows how organizations generate and use knowledge simultaneously, knowledge is treated as specific and distinctive resource, so it demands different treatment (i.e., it cannot be measured in the same way as fixed assets). Knowledge management was divided into four processes (but does not equate knowledge with information) in accordance with process model; from Japanese approach, two kinds of knowledge were taken: tacit and explicit. Model contains actions directed to sharing of tacit knowledge and codification of explicit knowledge.

The authors emphasize that knowledge management integrates capability of IT to process data and information and the ability of innovation (Bhatti, 2001; Malhotra, 2005; Akram, Siddiqui, Nawaz, Ghauri, \& Cheema, 2011). It gives the opportunity to receive appropriate funding, developing and controlling the use of the conditions, methods, and techniques to the processes related to knowledge, in order to generate value from intellectual assets or other resources based on knowledge. Practitioners of knowledge management represented by the consulting firms focused chiefly on its processes: development, transfer, codification, and utilization, creation of formal systems supported by IT, emphasizing benefits from conducting knowledge management: enhancement of the organization value in the eyes of customers and employees (Garner Group, McKinsey, Deloitte \& Touche, KPMG, APQC, Unilever, Ernst \& Young, PWC) (Walecka-Jankowska, 2011). This paper adopted the following definition of knowledge management: a structured set of activities aimed at acquisition (creation and location outside the organization), codification, transfer, utilization, and storage knowledge in organization, taking into account both knowledge workers and the organization and leading to a competitive advantage.

Knowledge management processes follow one another in the order and form "megaproces" with input and output. The processes that add up to the megaproces are: acquisition (creation and location outside the organization), codification, transfer, utilization, and storage knowledge in organization (Kowalczyk \& Nogalski, 2007). They form a logical sequence of events: the acquisition or development of knowledge followed by recording and codification of good practice (Figure.1)

Codification provides access to knowledge, thereby increasing the degree of dissemination of knowledge by transferring it. The last element is the use of knowledge that occurs as a result of increasing competence of 
employees and the organization as a whole. This leads to the closing of the cycle, as an organization with the new knowledge can see new possibilities of its creation and development. New knowledge is the first step in the cycle of knowledge management, which is oriented towards creation of mechanisms driving the cycle of creating knowledge, which is valuable to the organization, employees, and customers. Sources of knowledge, which constitute the beginning of a cycle: the output of using the knowledge in organization (e.g., improvements of procedures and organizational structure) or using the knowledge from customers, other organizations (that were not available and can significantly affect viability and competitiveness of the organization), the structural level (necessary to ensure the continuity of knowledge management in all its stages), and the integration level (visions and strategies for knowledge management and knowledge culture in organization). Business continuity is ensured by this cycle, due to the fact that it is directly related to the creation of customer value and determines the growth of strategic competences of organization and its employees. The cycle must focus on effective use of organizations tools and resources.

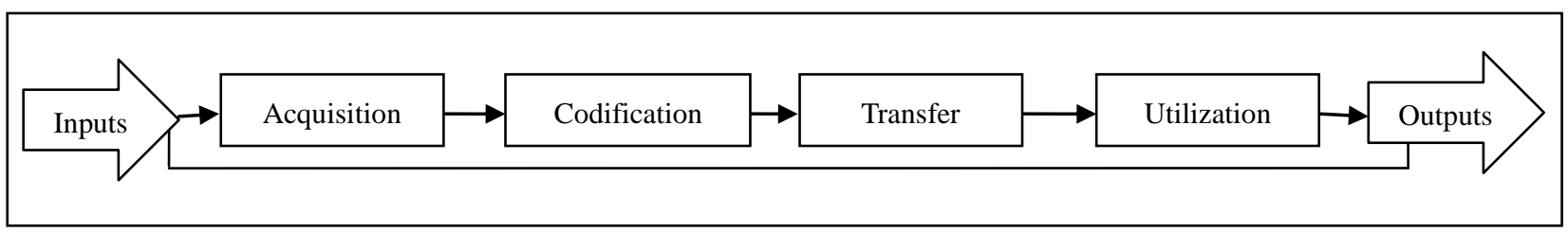

Figure 1. Megaproces of knowledge management.

\section{Relation Between Knowledge Management Processes and Innovation}

The general aim of first part of research was to define the determinants of the organizational innovation, with a particular emphasis on the knowledge management processes. These studies were conducted in Poland and 105 organizations operating in Poland were examined (they were different in terms of size, industry structure, and ownership structure). To investigate the results of the relation between innovation and knowledge management processes, the key variables were defined. The processes were devised into acquisition and development, codification, transfer, and utilization of knowledge which was adopted in the scale measuring the knowledge management.

The innovation was measured by the subjective indicator-degree of innovation, measured by five statements: Innovation in organizations is higher than that in the most important competitors; in the organization there are many ideas to improve organizational procedures; in the organization there are many ideas to improve the technological process; in the organization there are many ideas to improve products/services; and ideas which emerge in organization are often implemented. These items (put in form of statements) were rated by the respondents with Likert scale (five items scale). Cronbach's $\alpha$ was 0.861 , which indicates a very high internal reliability of the scale and measurement.

Stepwise regression analysis was performed. Fitting model was obtained in three steps $(F(1.104)=51.969$, $p<0.001)$. Obtained predictors can explain almost $70 \%$ of the variance of the variable innovation. Table 1 contains the structural parameters of the constructed model: innovation $=F$ (future-oriented strategy, acquisition and development of knowledge, and leadership dispersed).

Considering the subject of this article, the most important conclusion from this analysis refers to knowledge management. The analysis has shown that the only knowledge management process statistically significant in explaining the degree of innovation is knowledge acquisition. As indicated in Table 2, the other 
processes do not have statistically significant correlation with innovation. Thus, acquisition and development of knowledge should be the most important knowledge management process in innovation-oriented organization.

Table 1

The Regression Analysis Results

\begin{tabular}{|c|c|c|c|c|c|}
\hline \multirow{2}{*}{ Model } & \multicolumn{2}{|c|}{ Non-standardized coefficients } & \multirow{2}{*}{$\begin{array}{l}\text { Standardized } \\
\text { coefficients } \\
\text { Beta }\end{array}$} & \multirow[t]{2}{*}{$T$} & \multirow{2}{*}{ Significance } \\
\hline & $B$ & Standard error & & & \\
\hline (Constant) & 0.112 & 0.287 & & 0.390 & 0.697 \\
\hline Future oriented strategy & 0.438 & 0.107 & 0.373 & 4.110 & 0.000 \\
\hline Acquisition and development of knowledge & 0.328 & 0.094 & 0.294 & 3.493 & 0.001 \\
\hline Distributed leadership & 0.263 & 0.110 & 0.224 & 2.384 & 0.019 \\
\hline
\end{tabular}

Table 2

Results of the Regression Analysis for Knowledge Management Processes

\begin{tabular}{llllll}
\hline \multirow{2}{*}{ Model } & \multicolumn{2}{c}{ Non-standardized coefficients } & \multicolumn{2}{c}{$\begin{array}{c}\text { Standardized } \\
\text { coefficients }\end{array}$} & \multirow{2}{*}{$T$} \\
\cline { 2 - 5 } & $B$ & Significance & \\
\hline (Constant) & 1.076 & 0.256 & & 4.205 & 0.000 \\
Acquisition and development of knowledge & 0.509 & 0.157 & 0.456 & 3.245 & 0.002 \\
Codification of knowledge & 0.039 & 0.141 & 0.040 & 0.277 & 0.782 \\
Transfer of knowledge & 0.143 & 0.133 & 0.132 & 1.070 & 0.287 \\
Utilization of knowledge & 0.077 & 0.075 & 0.110 & 1.023 & 0.309 \\
\hline
\end{tabular}

Scale of acquisition of knowledge was built on the 16th position and the author carried out the item analysis, resting on the discrimination coefficient and Cronbach's $\alpha$ parameter. One item was excluded from the scale, because the discrimination coefficient for it was lower than 0.2. The final scale included 16 items (items were put in form of statements rated by the respondents with Likert scale (five items scale) - listed in Table 3) and Cronbach's $\alpha$ coefficient was 0.886 , which bears witness to the very high internal consistency of the scale and the reliability of the measurement.

Table 3

Items of Knowledge Acquisition

\begin{tabular}{|l|l|l|l|}
\hline \multicolumn{2}{|l|}{ Knowledge acquisition } \\
\hline $\begin{array}{l}\text { Organization seeks to acquire } \\
\text { knowledge by comparing with } \\
\text { the best ones in the industry }\end{array}$ & $\begin{array}{l}\text { Good solutions are copied } \\
\text { between different departments }\end{array}$ & $\begin{array}{l}\text { Specified procedures related to } \\
\text { the development of knowledge } \\
\text { within the organization are } \\
\text { implemented }\end{array}$ & $\begin{array}{l}\text { Organization identifies the } \\
\text { characteristics and skills } \\
\text { (competencies) required of } \\
\text { prospective employees }\end{array}$ \\
\hline $\begin{array}{l}\text { Employees are sent to other } \\
\text { organizations for trainings and } \\
\text { internships }\end{array}$ & $\begin{array}{l}\text { Employees have access to the } \\
\text { journals that are subscribed by } \\
\text { the organization }\end{array}$ & $\begin{array}{l}\text { Organization seeks to acquire } \\
\text { knowledge from their } \\
\text { customers }\end{array}$ & $\begin{array}{l}\text { Organization has a mechanism } \\
\text { to guarantee the design of new } \\
\text { solutions, which gives } \\
\text { participants: finance, freedom } \\
\text { and substantive support }\end{array}$ \\
\hline $\begin{array}{l}\text { There are key communities that } \\
\text { are developing knowledge in } \\
\text { the organization }\end{array}$ & $\begin{array}{l}\text { There are professional } \\
\text { networks in the organization }\end{array}$ & $\begin{array}{l}\text { There is a R \& D department in } \\
\text { organization }\end{array}$ & $\begin{array}{l}\text { There are communities of } \\
\text { practice in the organization }\end{array}$ \\
\hline $\begin{array}{l}\text { Specified procedures related to } \\
\text { design of new/improved } \\
\text { production processes/services } \\
\text { are implemented in the } \\
\text { organization }\end{array}$ & $\begin{array}{l}\text { Organization uses external } \\
\text { knowledge such as purchased } \\
\text { reports, licenses, patents }\end{array}$ & $\begin{array}{l}\text { Teams of employees from } \\
\text { different departments of the } \\
\text { organization are formed to } \\
\text { deliver specific project }\end{array}$ & \\
\hline
\end{tabular}


Therefore, it can be concluded that the more activities are in place to support the development and acquisition of knowledge, the higher the innovativeness of the organization is (Figure 2). The acquisition and development of knowledge requires targeted action at the level of the organization (for example, innovation-oriented structure), active employees and tools that can support knowledge management processes.

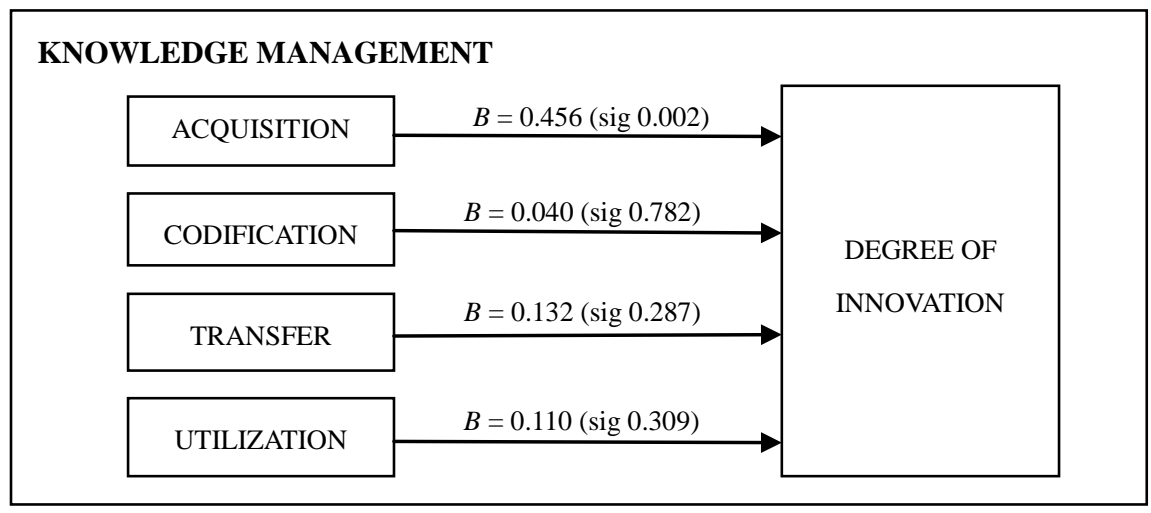

Figure 2. Relation between knowledge management and innovation.

\section{Knowledge Acquisition and Innovation}

Knowledge in an organization is formed in a discreet and unnoticed way during the search for a solution of problems or is introduced by people working inside or outside the organization (Brilman, 2002). One of the key elements of knowledge management is to obtain a clear picture of the internal and external resources: data, information, and knowledge. Nature of knowledge assets does not allow for complete freedom while buying or selling it. Teece (1998) argued that knowledge has to be built by the organization itself and developed for maximum efficiency. Another important issue is the presence of not only explicit knowledge, but also a hidden one-acquiring and codifying that it is difficult. Despite of difficulties with trading knowledge, it becomes the subject of the transactions (especially the knowledge of individuals). Rooting of organizational knowledge in processes, procedures, structures, and daily activities makes trade to be far more difficult. Another source of knowledge organization is contacts with customers, partners, and competitors. At any time, people have a key role in the knowledge acquisition process, the people are like sensors cooperating actively with the environment and thus ensuring the understanding of the complexity of the processes taking place in the environment of the organization. Gaining knowledge from outside of the organization (brand new) is the end result of knowledge acquisition process. Knowledge within the organization may be a subject of the development process that takes place in three stages: identification, development, and utilization. Developing knowledge (consciously and unconsciously) includes actions increasing the stock of knowledge. The process of knowledge development should take place without interfering with daily duties of all employees, while providing a systematic problem-solving through the use of creative thinking. Systematic action makes knowledge development a permanent component of organization operation - it should not be a random set of actions. Tools that can be used in acquiring the knowledge: benchmarking, collaboration with other organizations, training and practice, the subscribed reading for employees, knowledge takeover, acquiring it from outside (e.g., customers), and knowledge development (evolution of resources, mergers of internal departments and employees, networking, and establishing professional communities - both internal and external). A key role in development of knowledge is the selection of appropriate employees (with appropriate qualifications, but also with the motivation to expand both theirs and organizations knowledge-knowledge workers). In the knowledge-based 
organizations, the recruitment process and its effects play an important role. The organization's activities should be based on clear rules and principles. Employees must be aware of what is allowed, what forbidden, what discouraged, and what punished. The knowledge gained and developed at this stage must then be structured and stored - it is the aim of the next process - the codification and spread (transfer process) and used effectively leading, among others, to increase the level of innovation of the organization.

One of the conditions of rational course of the innovation process is the efficiency of the information and decision-making processes. Knowledge management plays a very important role in innovation processes, because the generation of ideas and development of original solutions need to go beyond the boundaries of knowledge and experience possessed at the time. Management of knowledge processes enables the reduction of ignorance area of ignorance, giving employees the freedom of contact through many different channels, thus, providing access to knowledge to different groups: senior managers, lower-level managers, project managers, professionals from research and development, and also employees.

Obtaining information from the environment requires deliberate actions from organization (in the form of: market research, benchmarking, tracking the development of technology, etc.). However, it requires active participation by all its participants, who, in the context of improving their qualifications and for task realization, seek information not only inside the company but outside of it. It is increasingly emphasized that the responsibility for monitoring the environment lies in hands of all employees-even in search for information about directions in which knowledge related to their work develops (Walecka-Jankowska, 2011). Hence, the methods of obtaining information from the environment must be decentralized, far from standardized and increasingly informal. Extremely unfavorable situation is when employees assume that all the information necessary to perform their tasks can be found inside the organization (e.g., received from supervisors). At the same time, it is important to notice that too much information can be just as bad as their deficiency.

As a result of perceiving new external knowledge, organization can opt to buy ready-made knowledge from the outside (e.g., licenses and franchises based on research contracts or by the employment of specialists), to use the experiences of other organizations or to co-create knowledge together with external partners. According to Walecka-Jankowska and Zgrzywa-Ziemak (2006), two last ways of acquiring external knowledge require development of inter-organizational relationships, which can be accomplished in various forms: loose and often informal trade cooperation, subcontracting or even different types of strategic alliances (Walecka-Jankowska, 2011).

Knowledge acquisition from inside of the organization refers to one of the sub-processes of knowledge conversion defined by Nonaka and Takeuchi (1995). In the context of identified knowledge gaps, it is possible to monitor the organization in order to externalize the knowledge held by specific individuals or groups. Knowledge is important from the perspective of other employees or the organization as a whole. This may take the nature of monitoring targeted by a properly designed reporting system, which, to some extent, can be supported by IT systems. These systems, in conjunction with certain procedures, may require implementation of specific knowledge into the system by certain employee at a certain time.

\section{Organizational Innovation and Organizational Structure}

There are different approaches to innovation, related to different scientific disciplines in which this term originated (in organization theory, economics, sociology, and technology). Most authors emphasize the aspects of the organization's search for new solutions in response to changes in the environment (both changes in 
customer needs and changes in organizational environment elements such as technology). Innovation is commonly interpreted as the introduction of a new product and is associated with the production process, especially technology. More rarely is it related to organizational, administrative, and cultural changes. The differences in the definition of this concept are also determined by the understanding of innovation as a process or as a result/outcome of a process. However, most definitions emphasize innovation novelty understood objectively (the macroeconomic view: Innovation is something absolutely new, pioneering work) and subjectively (the microeconomic view: It is new to the organization, developed and implemented regardless of whether such a solution exists in other organizations). Another common element is that innovation has to lead to the success of the organization by improving the use of resources or generating socio-economic benefits and thereby to improve the competitive position of the organization. The word "introduced" is also key here, since an important aspect is the implementation of innovation, not just theoretical assumptions or a new idea (Walecka-Jankowska, 2011). Undoubtedly, innovative activity in organizations should also be reflected in economic profit, personal development of employees, higher job satisfaction, better communication within the organization, the increase of knowledge and experience resources, the increase of production and economic indicators.

For the research, it was assumed that innovation is a change in the subjective sense (change is new only for the organization) leading to an improved product, production process, or organization itself, which was developed to achieve economic or social benefits. Innovation is also the process, in which the final step is to implement new ideas. Thus, innovation is not only the ability of the organization to create the idea, but it should also lead to economic and/or social benefits. It must be completed by the emergence of innovations on the market. The activities related to innovation include changes in both the incremental and radical transformation of the existing solutions. However, the adoption of the subjective understanding allows to achieve a high level of innovation, even if the organization implements the changes that exist in other entities, especially when they contribute to the improvement of the organization (Walecka-Jankowska, 2011).

It is important to notice that type of organizational structure (organizational configuration) is an important factor that can support or discourage innovation processes in organization. Flexibility and agility are characterizing structures in innovation-oriented organizations (de Mello, Marx, \& Salerno, 2010). It can be concluded that factors, which have been proven to be the most important for innovation should facilitate organic-type structure in organization (more flexible and agile then mechanistic structure). Organic-type structures are characterized by low centralization, low formalization, low specialization, and simple hierarchy.

\section{IT Functions Role in Knowledge Management}

Role of IT in knowledge management is considered important by many authors. At first, IT support for knowledge management consisted of simple document management systems. The reason why many authors, even in late 90's, suggested that IT is rarely a big support for knowledge management (especially knowledge acquisition processes) (Davenport \& Prusak, 1998; Nonaka, Reinmoller, \& Toyama, 2001) is that more complex knowledge management systems with implemented IT functions discussed in point 2.1 (not only document management systems but also Groupware, expert systems, semantic networks, relational and object oriented databases, simulation tools, and artificial intelligence) were not common until 21st century. Recently, even newer kinds of IT systems based on self-governing social computing tools (networks and communities) were introduced, partly because some authors made changes, for example, Nonaka, von Krogh, and Voelpel 
(2006) revisited their earlier work and made another attempt to describe knowledge management problems, taking into account today's reality. Nowadays, in many sources proposing IT taxonomy, IT for knowledge management is listed as a distinguished type of IT systems (Carbonara, 2005), so it can be concluded that the hypothesis that IT cannot support knowledge management is no longer viable.

In this article, IT in organization is considered as a group of IT systems (used by employees in organization) with implemented set of IT functions. IT functions are construed as some specific, typical uses of these technologies (Klonowski, 2004; Tworek \& Martan, 2015). Over the years, in the literature there have been many attempts to create this functions classification. Carbonara (2005) has proposed one of the most comprehensive taxonomy of IT functions. She identified following functions:

- transactional functions - supporting the transformation of unstructured processes in structured transactions. Most often occur in systems, such as ERP (enterprise resource planning systems) and PSI (process support and improvement systems);

- geographical functions - supporting easy and fast data transfer, regardless of the distance between employees, leading to the independence of the processes from geographic location. Most often occur in systems, such as ERP, DAA (data access and analysis systems and communication systems);

- automational functions - supporting reduction of the need for employees participation by replacing them with IT, freeing them from repetitive work. Most often occur in systems, such as ERP and PSI;

- analytical functions - supporting the use of complex analytical methods for the analysis and evaluation of the processes occurring in organization. Most often occur in systems, such as MDS (management decision support) and DAA;

- informational functions - supporting the deliverance into IT and processing of data contained in various forms: text, graphics, sound, and video. Most often occur in systems, such as DAA and communication systems;

- sequential functions - supporting changes in processes sequence enabling the possibility of simultaneous and coordinated completion of tasks in the process. Most often occur in systems, such as ERP and PSI;

- knowledge management functions - supporting distribution of knowledge and professional expertise among employees. Most often occur in systems, such as DAA and communication systems;

- tracking functions-supporting real-time tracking of tasks completion in processes taking place in organization. Most often occur in systems, such as MDS , ERP, DAA, and communication systems;

- interactive functions - supporting direct communication of two or more employees (synchronous or asynchronous), so they do not have to communicate through a third party. Most often occur in systems, such as DAA and communication systems.

\section{IT Information Function in Knowledge Acquisition}

In case of innovation, the most important process of knowledge management is knowledge acquisition, which was determined in point 1.3. Therefore, it is important to focus on this IT functions, which can help with knowledge acquisition in organization. It can be said that all IT functions can support this process but one of them is crucial-information function. Without information function, knowledge acquisition process (especially implementing new knowledge into IT systems) is unstructured, chaotic, and inefficient - this is the only function that enables structured and organized gathering of implicit and explicit knowledge from outside of the implemented in organization information systems. It is crucial to remember that it is necessary to get the 
knowledge from its source (inside or outside of organization) in order to do anything with it, using all other IT functions, for example, knowledge management functions are focused on distribution of knowledge that is already implemented into IT systems - implemented in organized way, using IT informational functions. It can be added that main issue raised nowadays is that it became more and more difficult to acquire "meaningful re-usable knowledge" and then ensure that it is properly included into IT systems existing in organization, so it can be a subject of codification, transfer, utilization, and storage later. It is important to remember that, undoubtedly, if the knowledge is not properly included into existing IT systems, knowledge management support by IT is more difficult and less efficient.

Furthermore, Gupta, Iyer, and Aronson (2000) underlined that technology is secondary to a human element in the knowledge management and that managers obtain two-thirds of their information from conversations with people, not from information systems directly. This is one of ways in which knowledge management can support innovation in organization. It can be said that in case of innovation-oriented organizations, IT should be able to help not only with acquisition of the knowledge (and implementing the knowledge into existing IT systems) and then, but more important, with finding the employee from which user can directly get this knowledge. Therefore, from organization point of view, it is obvious that the most important IT functions, which can support this task, are the information functions. Mainly because this is the only function which allows organized processing of information in order to properly include them in existing in organization IT system, and structured and organized gathering of knowledge is the only way to ensure that owner of knowledge is properly assigned to implement new knowledge. Thus, only then the knowledge can be used and converted by employees using all other IT functions.

\section{Relation Between IT Information Functions and Organizational Structure in Innovation-Oriented Organizations}

The general aim of second part of research was to verify the relation between IT interactive functions and organizational structure in order to determine if IT interactive functions may be the factor through which acquisition of knowledge supports introduction of organic-type structure, better for innovation-oriented organizations (Figure 3). Second part of studies was conducted in Poland in 2012 (Tworek, 2014). One hundred and five organizations operating in Poland were examined (they were different in terms of size, industry structure, and ownership structure). All of these organizations have implemented IT systems (they were different in terms of dissemination, user acceptance, and type - construed as number and nature of implemented IT function) and claimed that IT is used, among others, to support knowledge management.

To investigate the results of the relation between IT interactive functions and organizational structure, the key variables describing four organizational structure dimensions were defined: hierarchy, centralization, formalization, and specialization. Subjective level of each variable was calculated as the arithmetic mean of grades given to each item describing one of four variables. Items were put in form of statements and they were rated by the respondents with Likert scale (five items scale) (list of items - statements-for each variable is included in Table 4). It is worth noting that Cronbach's $\alpha$ was 0.641 and higher for every variable, which indicates a high internal reliability of the scales and measurements.

Research has shown that organizations, in which IT with information functions were implemented are characterized by lower hierarchy level $(\Delta H=0.4417)$, significantly lower centralization $(\Delta C=0.5403)$, lower formalization $(\Delta F=0.4415)$, and significantly lower specialization $(\Delta S=0.6306)$ (Table 5). So it can be 
concluded that organization with implemented IT information functions operates based on more organic structure then those, in which IT information functions were not implemented. It is worth mentioning once more that more organic structure is more suitable for innovation-oriented organization.

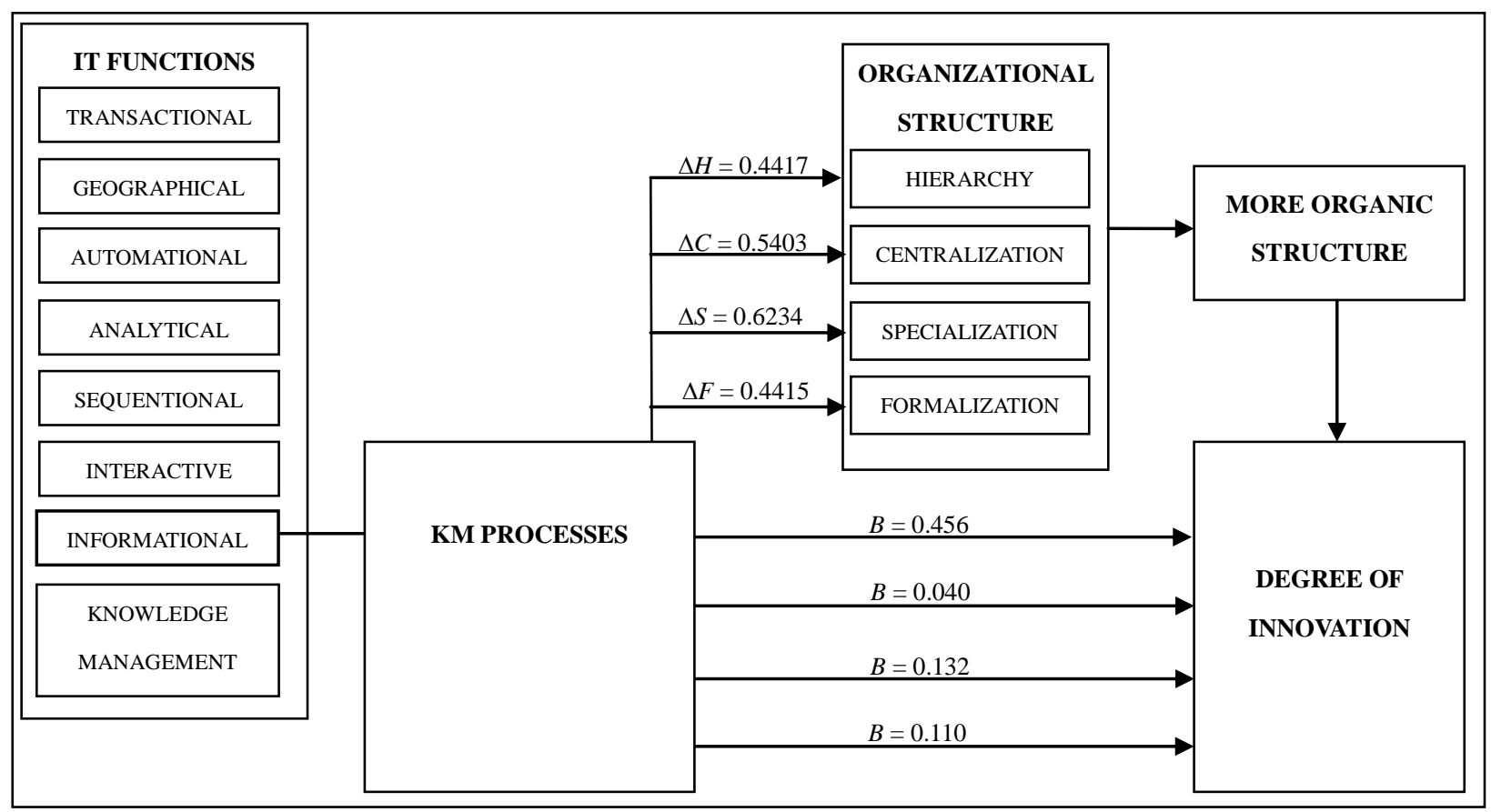

Figure 3. IT functions influence on organizational structure.

Table 4

Items of Organizational Structure Dimensions

\begin{tabular}{|l|l|l|l|}
\hline Hierarchy & Centralization & Formalization & Specialization \\
\hline $\begin{array}{l}\text { Organizational structure is } \\
\text { complicated }\end{array}$ & $\begin{array}{l}\text { Decisions concerning response } \\
\text { to environment change are made } \\
\text { on highest hierarchy level }\end{array}$ & $\begin{array}{l}\text { Number of organizational } \\
\text { documents is high }\end{array}$ & Tasks are simple and repetitive \\
\hline $\begin{array}{l}\text { Number of hierarchy levels is } \\
\text { high }\end{array}$ & $\begin{array}{l}\text { Decisions concerning } \\
\text { intellectual capital are made on } \\
\text { highest hierarchy level }\end{array}$ & $\begin{array}{l}\text { Degree of documents details is } \\
\text { high }\end{array}$ & $\begin{array}{l}\text { Number of production workers } \\
\text { is high }\end{array}$ \\
\hline $\begin{array}{l}\text { Number of direct subordinates } \\
\text { of managers is high }\end{array}$ & $\begin{array}{l}\text { Decisions concerning } \\
\text { manufacturing technologies are } \\
\text { made on highest hierarchy level }\end{array}$ & $\begin{array}{l}\text { Number of regulations } \\
\text { concerning ways of } \\
\text { accomplishing tasks is high }\end{array}$ & $\begin{array}{l}\text { Number of non-production } \\
\text { works is high }\end{array}$ \\
\hline $\begin{array}{l}\text { Managers will not be able to } \\
\text { manage more subordinates then } \\
\text { they are managing now }\end{array}$ & $\begin{array}{l}\text { Operational decisions are made } \\
\text { in place of the problem }\end{array}$ & $\begin{array}{l}\text { Regulations concerning } \\
\text { employees communication are } \\
\text { formal and restricted }\end{array}$ & Task rotation is common \\
\hline
\end{tabular}

Table 5

Organizational Structure in Companies With and Without It Information Functions

\begin{tabular}{llllll}
\hline & $\begin{array}{l}\text { Number of } \\
\text { companies }\end{array}$ & Hierarchy & Centralization & Formalization & Specialization \\
\hline $\begin{array}{l}\text { Companies with interactive } \\
\text { functions }\end{array}$ & 71 & $Z H_{f}=2.3825$ & $C_{f}=3.6068$ & $F_{f}=2.7798$ & $S_{f}=2.3774$ \\
$\begin{array}{l}\text { Companies without interactive } \\
\text { functions }\end{array}$ & 28 & $Z H_{n f}=2.8242$ & $C_{n f}=4.1471$ & $F_{n f}=3.2213$ & $S_{n f}=3.0008$ \\
$\Delta$ & & $\Delta Z H_{n f}=0.4417$ & $\Delta C_{n f}=0.5403$ & $\Delta F_{n f}=0.4415$ & $\Delta S_{n f}=0.6234$ \\
\hline
\end{tabular}




\section{Conclusions}

First part of presented research was aimed at concluding which knowledge management process is crucial for innovation-oriented organizations (in order to conclude what are the factors influencing structure reorganization to better facilitate innovation). It was concluded that knowledge acquisition is the only important knowledge management process in this term and its relation with organizational innovation is statistically significant (also, it is one of three factors placed in regression model for innovation). Relation between other three knowledge management processes and organization innovation was not proven to be statistically significant.

Therefore, next step of research was aimed at determining which IT functions are necessary for the IT to support knowledge acquisition. It was concluded that IT information functions are crucial in accomplishing this task. Thus, the second part of presented research was aimed at concluding if IT information functions (as an important component which allows the knowledge acquisition) can influence organizational innovation by facilitating reorganization to organic-type structure (more adequate for innovation-oriented organizations). The research has shown that organizations with implemented IT information functions were characterized by lower hierarchy level, significantly lower centralization, lower formalization, and lower specialization. So it was concluded that this organizations operate based on more organic-type structure (structure, which is significantly better for innovation-oriented organizations) then those, in which IT information functions were not implemented.

So, it can be concluded that IT information function supports the acquisition of knowledge (for example, by proper implementation of new knowledge in existing IT systems) and makes it easier for organization. They contribute to reorganization of organizational structure to more organic-type one and because of that, they may be the factor through which knowledge management supports innovation in organization (contributing to introduction of more flexible and agile structure, better for innovation-oriented organization). Therefore, it has been proven that IT has an influence on organization innovation.

\section{References}

Akram, K., Siddiqui, S. H., Nawaz, M. A., Ghauri, T. A., \& Cheema, A. K. H. (2011). Role of knowledge management to bring innovation: An integrated approach. Cell, 92(333), 121-134.

Bhatti, G. D. (2001). Knowledge management in organizations: Examining the interaction between technologies, techniques, and people. Journal of Knowledge Management, 5(1), 68-75.

Brilman, J. (2002). Nowoczesne koncepcje i metody zarządzania (Modern concepts and methods of management). Warszawa: PWE.

Carbonara, N. (2005). Information and communication technology and geographical clusters: Opportunities and spread. Technovation, 25, 213-222.

Crowston, K. (2000). Processes as theory in information systems research. Proceedings from International Working Conference on the Social and Organizational Perspective on Research and Practice in Information Technology.

Davenport, T. H., \& Prusak, L. (1998). Working knowledge. Boston: Harvard Business School Press.

de Mello, A. M., Marx, R., \& Salerno, M. (2012). Organizational structure to support innovation: How do companies decide? RAI: revista de administração e inovação, 9(4), 5-20.

Gupta, B., Iyer, L. S., \& Aronson, J. E. (2000). Knowledge management: Practices and challenges. Industrial Management \& Data Systems, 100(1), 17-21.

Klonowski, Z. J. (2004). IT systems of entrepreneurial management: Development models and functional properties. Wroclaw: Oficyna Wydawnicza Politechniki Wroclawskiej.

Kowalczyk, A., \& Nogalski, B. (2007). Zarządzanie wiedzą. Koncepcja i narzędzia (Knowledge management. Conception and tools). Warszawa: Difin. 
Liao, S. H. (2003). Knowledge management technologies and applications-Literature review from 1995 to 2002. Expert Systems With Applications, 25(2), 155-164.

Malhotra, Y. (2005). Integrating knowledge management technologies in organizational business processes: Getting real time enterprises to deliver real business performance. Journal of Knowledge Management, 9(1), 7-28.

Nonaka, I., \& Takeuchi, H. (1995). The knowledge-creating company. New York: Oxford University Press.

Nonaka, I., Reinmoller, P., \& Toyama, R. (2001). Integrated information technology systems for knowledge creation. In M. Dierkes, A. Berthoin, J. Child, and I. Nonaka (Eds.), Handbook of organizational learning and knowledge (pp. 827-848). New York: Oxford University Press.

Nonaka, I., Von Krogh, G., \& Voelpel, S. (2006). Organizational knowledge creation theory: Evolutionary paths and future advances. Organization Studies, 27(8), 1179-1208.

Teece, D. J. (1998). Capturing value from knowledge assets: The new economy, markets for know-how, and intangible assets. California Management Review, 40(3), 55-79.

Tworek, K. (2014). Information technology influence on organizational structure (Ph.D. Thesis. Wroclaw University of Technology, Wroclaw).

Tworek, K., \& Martan, J. (2015). Suitability analysis of a new method for measuring information technology acceptance. In J. Kowal (Ed.), Communication and information technology in society (pp. 133-148). Newcastle upon Tyne: Cambridge Scholars Publishing.

Walecka-Jankowska, K. (2011). The impact of knowledge management on innovation of enterprises (PhD Thesis, Wroclaw University of Technology, Wroclaw).

Walecka-Jankowska, K., \& Zgrzywa-Ziemak, A. (2006). Information technology participation in the processes of acquisition and distribution of knowledge (Scientific Papers of the Institute of Organization and Management of Wroclaw University of Technology). Wroclaw: Oficyna Wydaw. PWroc. 